Surgeon-Captain R. J. Baker, M.A., M.D., have been placed at the disposal of the Government of India in the Foreign Department. Veterinary-Captain F. J. Short has been appointed to the Civil Veterinary Department on probation and posted to the Central Provinces and Berar. SurgeonMajor J. C. Marsden has been appointed Civil-Surgeon, Negapatam, in succession to Surgeon-Major Bain. SurgeonCaptain A. Buchanan, Superintendent of the Raipur Central Gaol, has been appointed to the Charge of the Nagpur Central Gaol. Surgeon P. W. O'Gorman, I. M.S., Bengal Establishment, Medical Officer of the Mushkof-Bolan State Railway, has been transferred from the P. W. Department to the Home Department. Surgeon-Lieutenant-Colonel A. A. Macrobin assumed Charge of the Civil Medical duties of Kasauli on the forenoon of Dec. 2nd, 1892, relieving Surgeon-LieutenantColonel M. D. O'Connell. Surgeon-Captain E. D. BringhurstFarmar, A.M.S. has been granted an extension of leave from Dec. 7th 1892 to June 6th 1893 on medical certificate.

\section{Naval Medical Service.}

The following appointments have been made :-Staff Surgeons : Myles $\mathrm{O}^{\circ} \mathrm{C} . \mathrm{M}$ 'S winey to the Eagle (dated Jan. 5th, 1893) and J. A. Collot to the Collingrood (undated). Surgeons : Evan St. MI. Nepean to the Minotaur (dated Jan. 5th, 1893); John H. Stenhouse to the Collingnood (undated); James M. France to the Swiftsure (dated Jan. 11th, 1893). Surgeon and Agent: Thomas W. Pairman at Lyttelton, New Zealand, and James B. Lawson, M.D., at Rothesay (both dated Jan. 2nd, 1893).

\section{YEOMANRY CAVAILRY}

Hampshire (Carabiniers): Surgeon-Lieutenant G. F. A. England, M. B., to be Surgeon-Captain (dated Jan. 7th, 1893). Volunterer Comps.

Engineer: 1st West Riding of Yorkshire (Sheffield): Thomas Stewart Adair, M B., to be Surgeon-Lieutenant (dated Jan. 7th, 1893).--Rifle: 2nd Volunteer Battalion, the Gloucestershire Regiment : Honorary Assistant Surgeon C. W. Morris resigns his conımission (dated Jan. 7th, 1893). 1st Volunteer Battalion, Princess Charlotte of Wales (Royal Berkshire Regiment) : Surgeon-Captain J. H. Walters resigns his commission (dated Jan. 7th, 1893).--2nd Volunteer Battalion, the Duke of Edinburgh's (Wiltshire Regiment) Surgeon-Major E. N. Carless to be Surgeon-LieutenantColonel (dated Jan. 7th, 1893).

\section{INFANTRY VOLUNTEER BRIGADE.}

Manchester Brigade : Surgeon-Captain Duncan, M.B., 3rd Volunteer Battalion, the Manchester Regiment, to be Brigade-Surgeon-Lieutenant-Colonel (dated Jan. 7th, 1893).

\section{OBITUARY.}

Brigade-Surgeon J. Wallace, Retired List, Army Medical Staff, died at Hotel des Palmiers, Nice, on the 22nd uit. He joined the Army June 2nd, 1857; became Surgeon, March 1st, 1873; Surgeon-Major, April 1st, 1873; and retired with the honorary rank of Brigade-Surgeon May 30th, 1885. He served in the Afghan War of 1878-79 (medal), and also in the Soudan Expedition, under Sir Gerald Graham in 1884 (medal and Khedive's star).

\section{The New Royal Warrant.}

We understand that the privilege of counting twelve months of half-pay towards retirement lately conferred by Royal Warrant is to be enjoyed by all officers on the full-pay list at the time of its promulgation. The effect of this is that every officer now serving will benefit by the concession, whether he was on half-pay prior to the issue of the Warrant or not.

Surgeon-Colonel Preston, P.M.O.

The officers of the Medical Staff, Belfast district, entertained Surgeon-Colonel Preston, P.M.O., at dinner on the 28th ult., at the Royal Avenue Hotel, prior to his departure for Hong-Kong, he having been selected for the appointment of Principal Medical Officer of the China Station. The following were amongst those invited or present:-MajorGeneral Godfrey Clerk, C.B. ; Surgeon-Major-General J. Sinclair, Col. O'Grady Haly, D.S.O., A.A.G. ; Colonel Dawson, 83rd Regimental District; Lieutenant-Colonel Glencross, 1st Lancashire Fusiliers ; Lieutenant-Colonel Parker, R.E. ; Lieutenant-Colonel St. Paul, 2nd Rifle Brigade ; BrigadeSurgeon M Farland, Lieutenant-Colonel Challice, A.S. Corps Lieutenant-Colonel Brereton, A.P.D.; Major M. Johnson, D.A.A.G.; Major Holland, 15th Hussars ; Mr. Bond, Medical Staff Corps; Dr. Walton Browne, President, North of Ireland Branch, British Medical Association; and Dr. Whitaker President, Clster Medical Society.
Medical Examination of Militia OfFicebs. Successful candidates for commissions in the army will in future be inspected by a medical board after the competitive examination and no candidate will be considered eligible for a commission unless certified by the board to be physically fit in all respects for Her Majesty's service.

The HuRdwar Farr.

The Government of the North-Western Provinces and Oudh has appointed a committee to examine and report on the sanitary conditions of Hurdwar on the occasions of the great bathing fairs, consisting of the Sanitary Commissioner to the Local Government as president, with an engineer officer of experience and the magistrate of Saharanpur; and associated with these officials five Hindu gentlemen who have been requested to aid the Government with their advice. This is a wise policy to adopt, and we trust that measures will be derised for making the sanitary and other arrangements for these fairs satisfactory - especially in the way of securing a good water-supply for potable purposes and fresh running water for the bathing place of the pilgrims. Arrangements against overcrowding and fouling of the surface soil are also required, together with power to break up and disperse the assembly in case of need.

\section{'The New Ghrmax ARmy Bill.}

This continues to excite great attention in Germany and on the Continent generally. During the last twenty years the cost of military defences in Europe has nearly doubled and the enormous expenditure under which the nations aregroaning can scarcely be increased further -indeed, the wonder is how it can be borne, and how it is proposed to find the number of medical officers that will be required if these forces ever come into collision, armed as they are with quick-firing rifles and arms of precision. This great increase of European armies has taken place since the termination of the FrancoGerman War ; and the loss of Alsace-Lorraine by the French naturally gave rise to the enormous increase of their army, which is now said to number 4,350,000 men. If the new Army Bill passes the German army will in a few years have a strength of 5,000,000. The strongest military Power in Europe, however, is Russia, which has at its disposal $6,000,000$ soldiers to carry out a policy which can scarcely be described as one of peace and goodwill to men.

The Rupee and Indian Service.

Service in India is not very popular at the present time and medical officers are not likely to be attracted to that country by the emoluments it offers. The fallen and still falling rupee has become a serious question; meetings are being held in the large cities of India--by the Bombay branch of the Indian Currency Association, for example-at which resolutions are passed for petitioning the Government of India to urge the Secretary of State to sanction the immediate closing of the mints for the coinage of silver as the only prompt way of relieving the Government of its financial troubles. India, it is urged, is the only country where the mints are open to an unrestricted coinage of silver.

\section{Correspondence.}

$$
\text { "Audi alteram partem." }
$$

\section{"THE LATE DR. WALSHE." To the Editors of THE LANCET.}

Sins, - It would be a pity if no voice were to go forth from Scotland as a tribute to the late Dr. Walshe, and although it may be in one sense a superfluity to praise where all are of one mind, yet you will perhaps allow me a few lines to echo, as it were, the voices of your English correspondents. My acquaintance with Dr. Walshe (no doubt far less intimate than theirs) goes back a long way-to the time, in fact, when he was still a clinical teacher in University College Hospital and just emerging into consulting practice, in the presence of such men as Watson, Latham and C. J. B. Williams. Even in these days I can distinctly recall the impression on my own mind as an outsider (so to speak) in London professional circles that in precision of method and fulness of individual information Dr. Walshe was difficult to surpass, and I think I should bave placed him eren then first 
amongst English auscultators. In view of the successive editions of his (now subdivided) works on the heart and the lungs respectively, there will be few, I think, who will now question this precedency. In spite of a tendency to over-refinement, which makes it more difficult, perhaps, apart from the personal traditions of his teaching, to recommend these works to students, I have always placed them in the very front rank, giving explanations in detail where the difficulties come in, or where I fancy they come in, so as to be perplexing to stadents not bred in University College traditions or by Dr. Walshe's own pupils. This explained, Dr. Walshe's books are even now better worth studying in many respects than any of their more modern rivals, and certainly beyond all comparison superior in impartiality and breadth of view to Skoda's running commentaries on Laennec. The curious anecdote by Dr. Wilks in THF LANCET of to-day goes to show that, with all his admiration for Louis as his early teacher and his high estimate of the numerical method Dr. Walshe was fully alive to the limitations of the method and regarded it, as many of us now are disposed to regard the "preRaphaelite" school in art, as only a "stepping-stone to higher things." My personal opportunities of meeting Dr. Walshe occurred at such rare and distant intervals that the sum of them does not come to much, but I can well understand and appreciate all that is said of him from the higher point of view of his character and genius. Dr. Walshe's was not, however, the genius that scornfully rejects details or aims at posing in an attitude of mental superiority. He was nature minister et interpres, but chiefly and, above all, the latter. I am, Sirs, yours truly,

Glasgow, Jan. 7th, 1893. W. T. GAIRDNER, LL. D., M. D. Edin.

\section{BICARBONATE OF POTASH IN INFLUENZA. To the Editors of THE LANCET.}

SrRs, - In your "Annus Medicus 1892," under the heading "Therapeutic Progress," the following sentence occurs: "Influenza in the earlier part of the year, and cholera in the autumn, produced a crop of specifics of which little need be said beyond noting that the efficacy claimed for them was, as usual, greatest during the decline of the epidemics.' The writer seems to convey the impression that no progress worth noting has been made during 1892 in the treatment of influenza and cholera. I demur to the accuracy of this statement in the case of influenza. Three years ago, by a process of reasoning from facts placed at my disposal (as at the disposal of all) by the most reliable living bacteriologists, I hoped that I had found an effectual and speedy remedy for influenza. On July 16th, 1891, I communicated my discovery to the members of the Border Counties Branch of the British Medical Association in an address which, as president, my position imposed upon me.

An abstract of my address appeared in THE LANCET on Dec. 19th, 1891. I naturally watched the subsequent issues with expectancy, but the article seemed to me at the time to havefallen flat and to have arrested very little attention; however, it was not quite so, as I afterwards found out. You very liberally published a leader in THE LANCET of Jan. 23rd, 1892, calling the attention of the profession to my conclusions, but declining insertion of the evidence $I$ adduced as to the value of my remedy. The bold, fearless and fair statements in that leader more than atoned for the airs of superiority assumed by the writer. One of the best known and most respected teachers in the University of Edinburgh had previously stated, from personal knowledge, his full conviction of the thoroughly satisfactory character of the new treatment. I give his ipsissima verba from his letter now lying before me: "My strength never suffered, and indeed my rapid recovery and immunity from all of the unpleasant after-consequences of influenza made it somewhat difficult for me to believe that I had actually successfully combated an affection which has led to such consequences in some of its victims. However, there can be no doubt about the correctness of the diagnosis, the value of your remedy, or the satisfactory results of its energetic use." In the most manly and straightforward manner he has given me leave to make use of his name and experience in support of my contention. I refer to Dr. David Hepburn, F'.R.S. Edin. \&c. Out of the many communications which you must have received in response to your invitation, some from gentlemen well qualified from practical experience to form a reliable opinion, there were some which you did not insert. But $I$ assume, acting on your editorial judgment, that the two letters you printed
- the only letters that referred to me by nameplacing before the profession the general sense of their experience. Those letters were confirmatory of $\mathrm{my}$ position. Mr. Pugin Thornton of Canterbury (THE/LANCET, Jan. 30th, 1892, page 279), a well-known medical author, a valued contributor to Sir Richard Quain's Dictionary of Medicine, and a man of ripe experience and acute observation, says "During this epidemic I have used nothing else but bicarbonate of potash, giving it, as recommended by $\mathbf{M r}$. Crerar, in half-drachm doses in milk every three hours as long as the fever lasted. Last epidemic I gave salicylate of soda with bromide of ammonium, after an injection of apomorphia or an aperient, and the bicarbonate treat ment I find by far the best." This was not "during the decline of the epidenic," as asserted in your summary of Dec. 31st, 1892, but during the whole of the second epidemic from its commencement up to that date; and Mr. Thorntor draws a careful comparison between my treatment and the accredited treatment previously used, entirely to my advantage. I needed not Mr. Thornton's testimony, valuable as it is, to establish my contention:

\section{"It only serves to thicken other proofs}

That do demonstrate (by no means) thinly."

To any person reasonably open to conviction the evidence already placed before the profession is quite conclusive. I further affirm most emphatically that it was in severe cases. and in the acute stages of the epidemic that the value of $\mathrm{my}$ treatment was most conspicuous. Also let me not be misapprehended. The patient ought to be under the care of his physician, who will adopt the usual precautionary measures in such cases ; but the bicarbonate will be his sheet-anchor. Furthermore, as I intend when leisure serves to write a monograph on this subject, in which my views on the etiology. pathology and treatment of influenza will be fully expressed, unfettered by the limitations necessarily imposed on an article in a weekly journal, I will not trespass further on your valuable space. Meantime, as I have been singled out in your Annus Medicus for a thinly-veiled attack, I have confidence that you will in common fairness give me the opportunity of defending myself by inserting this apologia pro medicina mea. I am, Sirs, yours truly,

JoHN CRERAR, M.R.C.P. Edin.

We have been compelled to abbreviate Mr. Crerar's letter, but we think he is mistaken in supposing that we have received many communications on this subject. To the best of our recollection the letters referred to by him as being inserted in our columns were all that were received by us. We might also point out that the summary to which he takes exception refers to the year 1892 and not 1891, when he first drew attention to the efficacy of bicarbonate of potash in influenza. He must know that many other drugs have been alleged to be of specinc action in this disease by other writers in this country and abroad. We shall await his projectec monograph with interest. - ED. L.

\section{THE TEACHING OF THERAPEUTICS AT GLASGOW. \\ To the Editors of THE LANCET.}

SIRs,-At the last meeting of the Glasgow University Students' Representative Council Mr. de Hyde-Wytt submitted the following motion: "That in view of the change in the Medical Ordinance-which now reads Materia Medica and Therapeutics instead of the old reading, Materia Medica and Pharmacy - that a deputation wait upon the Senate requesting them to ask the managers and directors of the Western Infirmary to place wards at the disposal of the Professor of Materia Medica and Therapeutics in the University of Glasgow in order that he may be able to give full and proper instruction in that most highly important of the medical sciences-therapeutics, the art and science of healing." This was carried unanimously and referred to the Grand Committee in Medicine to take proper steps. As the result the latter body elected a deputation which will wait upor the Senate as soon as possible and ask their coöperation in rectifying the anomalous state of affairs which obtains : that Dr. Ir. Charteris, the Professor of Materia Medica and Therapeutics, having no wards at his disposition, can only teach therapeutics in the lecture room. This is preposterous for this subject is pre-eminently a practical one. When the 